\title{
Intellectual Capital Measuring and Reporting
}

\author{
Fatemeh Babai $^{1, *}$, Rogieh Niazy ${ }^{2}$, Maryam Talebi $^{3}$, Jamal Mohamade $^{4}$ \\ ${ }^{1}$ Accounting faculty member of Payame Noor University Zanjan \\ ${ }^{2}$ Master of governmental management, Supreme Audit Court of Iran, Zanjan Iran, \\ rogiehniazy@yahoo.com \\ ${ }^{3}$ Accounting lecturer at the University, maryam.talebi.2007@gmail.com \\ ${ }^{4}$ Accounting lecturer at the University, Supreme Audit Court of Iran, Mashhad, Iran, \\ mohamady_jamal@yahoo.com
}

*Corresponding Author: Fatemeh_babaei62@yahoo.com

\begin{abstract}
Intellectual capital (IC) is increasingly recognized as an important strategic asset for sustainable corporate competitive advantages. Intellectual capital is one of the most important intangible assets in the firms. Intellectual capital evaluation seems to be one of the most important topics in accounting and management. The new strategic management Theoretical literature and empirical evidences suggest that Intellectual capital has direct effect in the firm's value and performance. The aim of this research is to review literature of intellectual capital and importance of intellectual capital reporting in terms of our current economic business environment.
\end{abstract}

Keywords: Intellectual capital, human capital ,structural capital, relational capital, financial reporting.

\section{Introduction}

In the knowledge-based economy, the intellectual capital of the organization is to create value in today's world; the success of any organization depends upon the ability to manage these assets. Today, the growing importance of intellectual capital as an effective tool is for enhancing the competitiveness of our companies. Measuring intellectual capital in order to compare different companies is necessary to determine their true value and improve their controls. Knowledge of today's top tools of economics is, where heroic acts economics, science and technology, there is increasing use of information. Knowledge-based companies have a large proportion of their investments in intangible assets and for finance and accounting management for companies that traditionally have Unobtrusive performance in different financial situations did not reflect a real challenge of remains (Seetharaman et al, 2002). Intellectual capital, in one form or another, is implicated in recent economic, managerial, technological, and sociological developments in a manner previously unknown and largely unforeseen. Specifically, the importance of IC is emphasized in:

- the revolution in information technology and the information society;

- the rising importance of knowledge and the knowledge-based econom

- the changing patterns of interpersonal activities and the network society; and

- the emergence of innovation as the principal determinant of competitiveness.

However, whether these developments are viewed through the filter of the information society, the knowledge-based economy, the network society, or innovation, there is much to support the assertion that IC is instrumental in the determination of enterprise value and national economic performance (Petty and Guthrie,2000). Intellectual capital is an important intangible asset in today's business, particularly in current knowledge intensive economy which also relies heavily on technology. IC has been frequently recognized 
as invaluable intangible asset which is managed and utilized to stimulate innovativeness, creativity, competitive edge, value creation and boost corporate performance(Abdullah and Sofian, 2012).The related literature shows that there is no single definition for the intellectual capital. According to IASB, intellectual capital includes the non-financial fixed assets that are not financial by nature but are recognizable and controllable by companies. Based on such definition, the intellectual capital mainly includes patents, trademark, and good will. Since the intellectual capital becomes the key driver in providing improved performance (Roos et al, 2005). Intellectual capital assets are strategic resources that should be properly managed in order to derive maximum benefits from them. Effective management of these assets helps in their recognition, measurement and reporting (Holmen,2005). Measuring the benefits gained from possessing intellectual capital and the value of these assets has both internal and external purposes. In terms of internal purposes, a company would measure intellectual capital in order to manage its resources more effectively, and will, thereby, minimise costs. On the other hand, measuring intellectual capital for external purposes would require verifiable information that signals the expected growth of the company to existing and potential investors, and to other external users of the information (Hunter, Webster \& Wyatt, 2005). The process of measuring intellectual capital for both internal and external purposes involves using financial and non-financial measurement methods (Cronje and Moolman,2013)

\section{Elements of intellectual capital}

In general, researchers and those involved in the field of intellectual capital on this thing believed that the intellectual capital of three human capital, structural capital and relational capital, which may be explained as follows:

\section{A) Human Capital(HC)}

Roos et al (1997) argue that employees' intellectual capital is to develop through competence, attitude and intellectual agility to develop. The most important elements of human capital enterprise workforce skills sets on, depth and breadth of their experience. Human resources can be regarded as spirit, mind and intellectual capital resources. The capital's night out would remain unchanged, but leave the employees of the company, structural capital and relational capital even leave in the night. Human capital consists of: a) the skills and competencies of the workforce b) their knowledge in areas that are critical to business success, and c) the talents of their conduct. Brookings (1996) argues that human assets of an enterprise, including skills, expertise, abilities, problem solving and leadership styles. If an enterprise-level staff turnover is high, it may mean that the organization of this important component of your intellectual capital is lost.(Sharifi and Bijani,2014).

\section{B) Structural capital(SC)}

Structural capital is the second subject from classification of intellectual capital elements. Structural capital includes all non- human knowledge reserves in organizations. According to Stewart's view (1997), structural capital is the existing knowledge in IT, right of registration of products, brands and trademarks. Edvinsson and Malone (1997) describe structural capital including hardware, software, databases, structure, patent, trademarks, and all organizational capacities that support productivity in organization. Similarly, Brooking (1996) argues that structural capital comprises of infrastructural assets like technology, occupational processes and methods as well as intellectual assets such as know- how, trademarks and products registration right (copyright). While structural capital and organizational capital are utilized usually instead of each other but among of them, Pondent prefers to use term Organizational Capital. He considers organizational capital as an established knowledge in organization that is stored in database, instructions and etc. Concerning to such distinction, Pondent believes in that organizational capital interpret more clearly that in fact such knowledge belongs to organization. Roos et al. (1997) argue that structural capital includes whatever remained in an organization after the time when personnel leave it to go home at night like innovation, processes and culture, renewal and development capital, right of products registration and training efforts. In their opinion, structural capital also covers organizational 
capital. In general, one can consider structural capital including some components like culture, copyright or intellectual ownership, database(s), computerized systems, intranet, processes, Research and Development (R\&D), efficiency and effectiveness, procedures, policies, structure, organizational chart and strategies ( Hashemnia et al,2014).

\section{C) Relational capital (RC)}

Relational capital refers to the ability of an organization to interact with external stakeholders. RC is broadly defined as all resources linked to the external relationships of the firm, with customers, suppliers or R\&D partners(Meritum, 2002).Originally, this form of capital was part of structural capital (Edvinsson \& Malone, 1997).However, it emerged as a distinctive form of capital, primarily focused on relationships with customers and labeled accordingly customer capital. Later on, the concept was extended to cover all the various external connections of the firms and accordingly renamed relational capital. Reputation, which reflects the image that stakeholders have of the firm, is another key component of relational capital. This study adopts a broad definition of relational capital, encompassing the resources and activities that are mobilized and conducted by organizations when dealing with entities that are outside its boundaries (Mention,2012).

\section{Definitions of IC}

Several definitions are presented for intellectual capital structure in theoretical literature of economy and management fields. This term integrates intellectual power idea (brain potential) into economic concept of economy. On the one hand, some have defined this structure as disclosure of financial values resulting from innovations, inventions and human intellect and talent in organization while some others also considered it as knowledge- based assets of organization that contributes to acquisition of occupational goals (Hashemnia et al, 2014). Several definitions of IC is given in Table1 (Thiagarajan, and Baul,2014).

Table1: Definitions of IC

\begin{tabular}{|c|c|c|}
\hline Author(s) & Date & Definitions \\
\hline Becker & 1964 & $\begin{array}{l}\text { Investment in human capital, e.g individual's education and } \\
\text { training is similar to business investment in equipment }\end{array}$ \\
\hline Itami & 1987 & $\begin{array}{l}\text { Invisible assets such as information base assets, which include } \\
\text { technology, consumer trust, brand image, corporate culture as well } \\
\text { as management skills, are the most important resources for } \\
\text { organizational long term success. }\end{array}$ \\
\hline Hall & 1989 & $\begin{array}{l}\text { Intellectual assets, Intellectual property rights, i.e. Patents, } \\
\text { trademark, register design \& copy right, reputation, organizational } \\
\text { and personal networks, and the knowledge and expertise of skilled } \\
\text { employees }\end{array}$ \\
\hline Hall & 1992,1993 & $\begin{array}{l}\text { It consists of assets, i.e intangible property rights and reputations } \\
\text { and skills or competencies, i.e know- how and organizational } \\
\text { culture. }\end{array}$ \\
\hline $\begin{array}{l}\text { Klein and } \\
\text { Prusak }\end{array}$ & 1994 & $\begin{array}{l}\text { It is Intellectual material that has been formalized, captured and } \\
\text { leveraged to produce a higher value asset. }\end{array}$ \\
\hline $\begin{array}{l}\text { Edvinsson and } \\
\text { Sullivan }\end{array}$ & 1996 & It is knowledge that can be converted into value \\
\hline Brooking & 1996 & $\begin{array}{l}\text { It is a combination of four main components: market assets, } \\
\text { human centered assets, Intellectual property assets and } \\
\text { infrastructure assets. }\end{array}$ \\
\hline Sveiby & 1997 & $\begin{array}{l}\text { It is related to three categories of Intangible assets: internal } \\
\text { structure, external structure and human competence. }\end{array}$ \\
\hline Roos et al & 1997 & $\begin{array}{l}\text { It is composed of (and generated by) thinking part, i.e. The human } \\
\text { capital, and a non-thinking part, i.e. the structural capital. }\end{array}$ \\
\hline
\end{tabular}




\begin{tabular}{|c|c|c|}
\hline Author(s) & Date & Definitions \\
\hline $\begin{array}{l}\text { Roos and } \\
\text { Roos }\end{array}$ & 1997 & $\begin{array}{l}\text { Intellectual capital is the sum of the "Hidden" assets of the } \\
\text { company not fully captured on the balance sheet, and thus includes } \\
\text { both what is in the heads of organizational members, and what is } \\
\text { left in the company when they leave. }\end{array}$ \\
\hline Stewart & 1997 & $\begin{array}{l}\text { It is intellectual material - knowledge, information, intellectual } \\
\text { property, } \\
\text { experience - that can be put to use to create wealth. }\end{array}$ \\
\hline $\begin{array}{l}\text { Edvinsson and } \\
\text { Malone }\end{array}$ & 1997 & $\begin{array}{l}\text { It is the sum of human and structural capital, in non detail it } \\
\text { involves applied experience, organizational technology, customer } \\
\text { relationships and professional skills that provide an organization } \\
\text { with a competitive advantage in the market. }\end{array}$ \\
\hline Boisot & 1998 & $\begin{array}{l}\text { Subset of dispositions to act that is embedded in individuals, } \\
\text { groups, or arte facts and that has value adding potential. }\end{array}$ \\
\hline Teece & 1998 & $\begin{array}{l}\text { The firm-specific resources that are difficult if not impossible to } \\
\text { imitate. }\end{array}$ \\
\hline Bontis et al. & 1999 & $\begin{array}{l}\text { It is a concept to classify all organizational intangible resources as } \\
\text { well as their inter-connections. }\end{array}$ \\
\hline OECD & 2000 & $\begin{array}{l}\text { Economic value generated by two categories of intangible assets } \\
\text { of a company; organizational capital and human capital. }\end{array}$ \\
\hline Nonaka et al & 2000 & $\begin{array}{l}\text { Firm specific resources that are indispensable to create value for } \\
\text { the firm }\end{array}$ \\
\hline Lev & 2001 & $\begin{array}{l}\text { Intangible assets are non-physical sources of value (claims for } \\
\text { future benefits) generated by innovation (discovery), unique } \\
\text { organizational designs, or human resource practices. }\end{array}$ \\
\hline $\begin{array}{l}\text { Marr and } \\
\text { Schiuma }\end{array}$ & 2001 & $\begin{array}{l}\text { The group of knowledge assets that are attributed to are } \\
\text { organization and most significantly contribute to an improved } \\
\text { competitive position of this } \\
\text { organization by adding value to the defined key stakeholders. It } \\
\text { includes human assets, and physical assets. }\end{array}$ \\
\hline $\begin{array}{l}\text { Kaplan and } \\
\text { Norton }\end{array}$ & 2004 & $\begin{array}{l}\text { Intangible assets consist of human capital, i.e. skills, talent, and } \\
\text { knowledge, information capital, i.e., databases, information } \\
\text { systems, and technology infrastructure, organizational capital, i.e. } \\
\text { culture, leadership style, ability to share knowledge }\end{array}$ \\
\hline IASB & 2004 & $\begin{array}{l}\text { Intangible assets are non-financial fixed assets that do not have } \\
\text { physical substance but are identifiable and controlled by the entity } \\
\text { through custody and legal rights }\end{array}$ \\
\hline
\end{tabular}

\section{Reporting of intellectual capital}

Companies may want to measure intellectual capital for a variety of reasons. One study identified five main reasons. First, measuring intellectual capital can help an organization formulate business strategy. By identifying and developing its intellectual capital, an organization may gain a competitive advantage. Second, measuring intellectual capital may lead to the development of key performance indicators that will help evaluate the execution of strategy. Intellectual capital, even if measured properly, has little value unless it can be linked to the firm's strategy. Third, intellectual capital may be measured to assist in evaluating mergers and acquisitions, particularly to determine the prices paid by the acquiring firms. Fourth, using nonfinancial measures of intellectual capital can be linked to an organization's incentive and compensation plan. The first four reasons are all internal to the organization. A fifth reason is external: to communicate to external stakeholders what 
intellectual property the firm owns. Improving external reporting of intellectual capital can: (1) close the gap between book value and market value, (2) provide improved information about the "real value" of the organization, (3) reduce information asymmetry, (4) increase the ability to raise capital by providing a valuation on intangibles, and (5) enhance an organization 's reputation. The results of measuring intellectual capital also can be useful to investors. Let's look at three approaches to external reporting of intellectual capital.

\section{4-1- S FAS No. 142}

The Financial Accounting Standards Board 's (FA S B ) Statement of Financial Accounting Standards (SFA S ) No. 142, "Goodwill and Other Intangible Assets," provides the accounting basis for measuring intangible assets. An intangible asset that is acquired from an external source is initially recognized at its fair value. If an intangible asset is developed internally, it is recognized as an expense when it is incurred. This will limit the recognition of most intellectual capital to what is purchased from outside the organization, such as patents, licenses, and trademarks, because they are the only ones recognized as assets. Generally accepted accounting principles do not recognize a value of human capital nor much of the structural capital, such as internally developed software, patents, and brands. In developing the Statement, the FASB relied upon the four recognition criteria found in FASB Concepts Statement No. 5, "Recognition and Measurement in Financial Statements of Business Enterprises." These criteria are: (1) The item meets the definition of an asset, (2) the item is measurable with sufficient reliability, (3) the information is capable of making a difference in decisions, and (4) the information indeed represents what it claims to represent, is verifiable, and is neutral. As intellectual capital is a relatively new concept and there is no agreement on how to measure it, many intellectual capital items will fail on criterion two (reliability in measurement) and criterion four (verifiable). Until these two criteria can be met, it is doubtful whether many intellectual assets will be included in financial statements. Even so, the amount of intellectual capital a firm has can still be conveyed to investors(Holmen,2005).

\section{4-2- Value Chain Scorecard}

Baruch Lev has proposed a scorecard approach to provide investors and external decision makers with information relating to an organization's utilization of intellectual capital. In an economy with joint venture s and alliances, outsourcing, built-to-customer ordering, supply chain management and open source software, many important decisions are now made in consultation with partners in the value chain who are outside the organizational boundaries. Lev's scorecard provides no transaction and nonfinancial information to support these decisions made with others in the value chain. The scorecard mirrors three portions of the value chain: discovery and learning, implementation, and commercialization. Each of these three can, in turn, be subdivided into three additional categories for a total of nine categories. The first phase of the value chain is the discovery of new products or services. These ideas can be generated internally through R\&D efforts or employee networks, they can be acquired from outside the entity, and they can be identified through active and formal networks such as joint ventures, alliances, and supply chain integration. The second major phase of the value chain is the transformation of ideas into working products or services. This can be measured through a variety of milestones: patents, trademarks, or other intellectual property; passing formal feasibility hurdles; and, related to Internet technologies, quantitative measures of activity. The third phase of the value chain is the commercialization of the products or services. 
Customer measures could include brand value, marketing alliances, and customer churn. Performance indicators could include innovation revenues, market share, economic value added, and knowledge earnings. A final category would provide forward-looking information on the product/service pipeline. A variety of indicators can be chosen for each of the nine portions of the scorecard. The indicators should have three attributes: They should be quantifiable, they should be standardized so comparisons can be made across firms, and there should be statistical evidence to link the indicators to corporate value. Although much of this information is historical, it is not necessarily based on transactions. Thus, little will be found in the existing accounting information (Holmen,2005).

\section{4-3- Intellectual Capital Statements}

The Danish Ministry of Science, Technology and Innovation has published several reports introducing intellectual capital statements. The Danish Financial Statements Act (June 2001) requires supplementary disclosure of intellectual assets if they are likely to affect future earnings . The disclosures are required for all except the smallest enterprises (fewer than 50 employees) or sole proprietorships. An intellectual capital statement consists of four elements: a knowledge narrative, a set of management challenges, a set of initiatives, and a set of indicators. The knowledge narrative expresses how the products and services of the organization provide value to the user. It addresses such questions as: What product or service does the company provide? What makes a difference for the consumer? What knowledge resources are necessary to be able to supply the product or service? What is the relationship between value and knowledge resources? Management challenges include existing knowledge resources that should be strengthened and new knowledge resources that are needed. Three general types of challenges recognize that a company's knowledge lies in its information systems, the cooperation among employees, and the individual expert or group of experts. Each management challenge is made up of a number of initiatives, which are actions concerned with how to develop or obtain knowledge resources and how to monitor them. Questions that are addressed include: What are the existing and potential initiatives and objectives that relate to the company's knowledge management? How do the initiatives and objectives work? What initiatives can be used to boost the company's knowledge management? Indicators are the measures of the initiatives, expressed in effects, activities, and resources. They define the management challenges of the initiatives and make it possible to assess whether initiatives have been implemented and whether they have the desired effect (Holmen,2005).

\section{Measurement Models Intellectual Capital}

- Direct intellectual capital (DIC) methods. This method estimates the dollar value of intangible assets by identifying its various components. Once these components are identified, they can be directly evaluated, either individually or as an aggregated coefficient.

- Market capitalization methods (MCM). MCM calculates the difference between a company's market capitalization and the book value of its shareholders' equity as the value of its IC or intangible assets.

- Return-on-assets (ROA) methods. ROA method is the average pre-tax earnings of a company for a period of time divided by the average tangible assets of the company. The result is a company ROA that is then compared with its industry average. The difference is multiplied by the company's average tangible assets to calculate average annual earnings from the intangibles. 
Dividing the above average earnings by the company's average cost of capital or an interest rate, one can derive an estimate of the value of its intangible assets or IC.

- Scorecard methods (SCM). The various components of intangible assets or IC are identified and indicators and indices are generated and reported in scorecards or as graphs. SCM methods are similar to DIC methods, except that no estimate is made of the dollar value of the intangible assets. A composite index may or may not be produced (Thiagarajan, and Baul,2014)

\section{Conclusions}

In the past few decades, the economy has moved from an industrial to a knowledge economy. Consequently, basic factors of production now no longer comprise only natural resources, capital and labour, but also intellectual capital. Despite the shift from an industrial to a knowledge economy, the accounting framework and financial reporting have not changed sufficiently to include intellectual capital. The intellectual capital is defined as a set of the company's strategic sources, and in the current Knowledge-Based Economy, considered as an indispensable part of the Value Creation Process of the company. Intellectual capital is playing a developing role in companies' performance alongside other productive factors. The limitations on financial statements in explaining firm value underline the fact that the source of economic value is no longer the production of material goods, but the creation of intellectual capital. However, the accounting framework and financial reporting have not changed sufficiently to include intellectual capital.

\section{References}

[1] Abdullah, D, F ., and Sofian, S.( 2012), The Relationship between Intellectual Capital and Corporate Performance, Procedia - Social and Behavioral Sciences, Vol.40, pp. $537-541$.

[2] Cronje, C, J., and Moolman, S. (2013), Intellectual capital: Measurement, recognition and reporting, South African Journal of Economic and Management Sciences, Vol 16, No 1.

[3] Edvinsson, L. and Malone, M. (1997), Intellectual Capital: Realising Your Company's True Value by Finding its Hidden Brainpower. Harper Collins, New York, NY.

[4] Hashemnia, S., Naseri,S., and Tabatabaei, M. (2014), A strategic Review the Impact of Intellectual Capital Components on Organizational Performance in Sepah Bank Branches throughout Tehran Province, Journal of Educational and Management Studies Vol. 4, No. 1,PP. 46-56.

[5] Holmen, J. (2005), Intellectual capital reporting. Management Accounting Quarterly, Vol. 6,No.4, pp.1-6.

[6] Hunter, L., Webster, E. \& Wyatt, A.L. 2005. Measuring intangible capital: A view of current practice. Australian Accounting Review, Vol .15, No. 2, pp. 1-18.

[7] Mention, A, N.(2012), Intellectual Capital, Innovation and Performance: a Systematic Review of the Literature, Business and Economic Research, Vol. 2, No. 1,PP.1-37.

[8] Meritum Project. (2002), Guidelines for managing and reporting on intangibles. available at: www.urjc.es/innotec/tools/MERITUM\%20Guidelines.pdf.

[9] Petty, R., and Guthrie, J. (2000), Intellectual capital literature review Measurement, reporting and management, Journal of Intellectual Capital, Vol. 1 No. 2, pp. 155-176.

[10] Roos, G., Pike, S. and Fernstrom, L. (2005), Managing Intellectual Capital in Practice, ElsevierButterworth-Heinemann, Burlington, MA.

[11] Seetharaman, A., Sooria, H,H,B,Z. and Saravanan, A, S. (2002), Intellectual capital accounting and Reporting in the knowledge economy, Journal of Intellectual capital, vol. 3 No. 2, pp . 128-148.

[12] Sharifi Ranani, H., Bijani, Z. (2014), The Impact of Intellectual Capital on the Financial Performance of Listed Companies in Tehran Stock Exchange, Vol.4, pp.119-127.

[13] Thiagarajan, A., and Baul, U., (2014), Holistic Intellectual Capital Conceptual Offering for Empirical Research and Business Application, International Journal of Management, Vol. 3, No. 1, pp 31-50. 